\title{
When Plants Become Precious: Art, Culture, and Environmental Crises
}

\author{
Evelyn A. Armstrong
}

P.O. Box 249 Merritt, B.C. V1K 1B8 Canada

Copyright (C) 2015 by authors, all rights reserved. Authors agree that this article remains permanently open access under the terms of the Creative Commons Attribution License 4.0 International License

\begin{abstract}
Drawing on the multidisciplinary literature of visual culture, ecological theory, ecofeminism, and environmental philosophy, I trace developments in environmental art to join in the ethico-aesthetic. This tradition calls for reflective thought on the value of subjective perception and distinctive lived experiences. It also calls for respect for sentiment, imagination, and creative expression. To a greater degree, regardless of how bleak things appear, the ethico-aesthetic paradigm calls for getting involved in practical activities that have a future. In relation to art, my inquiry follows a range of cultural activities that support ideas about reuniting humanity with the beauty of the natural world. Through practical engagements, environmental artistic practices also support conservation and the protection of endangered ecological systems. Informed by the art cannon of unity and beauty, my focus is to exemplify artistic practices that ascribe value to nature for the sake of nature. From this line of thought, my presentation conveys the theme of hope for a good outcome for Planet Earth.
\end{abstract}

Keywords Environmental Art, Practical Activities, and the Theme of Hope

\section{Introduction}

In light of the global environmental and ecological crises, this paper represents an enquiry into the concepts conservation and preservation that are directed toward raising public awareness about changing environments. Critical to my analysis is an interest in the connection between nature and human culture. As I explore the realm of subjective and cultural symbols, in relation to art and social life, my focus is directed by a background belief that all things are interconnected. My schedule has been divided between a studio artistic practice, an art teaching career, and work as an apiary inspector with the British Columbia Department of Agriculture. As an artist teacher and beekeeper, I have had an extraordinary opportunity to live close to Nature and in my work, to travel to small and isolated communities throughout British Columbia, Canada.

Travel has brought me close to local and international cultural and artistic communities. I have had an opportunity to hear the voices of cross-cultural, land-based societies and their concerns about the impact of climate change; and I have listened to controversial issues of conservation. In my home province of British Columbia in the 1970s and well into the 1990s, there was little discussion about sustainable farming or forests - let alone land conservation or plant preservation. The economic conversation encircled "mega" projects: the damming of majestic rivers for hydro-electric power, massive energy extraction in mining, clear-cut logging in the forests; and in the sports and fishing industry, it was all about "catch" rather than release.

While different theories examine environmental problems, from the "growth imperative" and the rise of global economics, the industrial civilization underscores the fact that people the world over rely upon the Earth's energy and upon the bounty of Nature for the essential ingredients of life. Meanwhile industrial progress, economic development, and the growing demand for minerals, timber, oil and gas contributes to the "rapid and catastrophic degradation of the planetary biosphere." [1]

The eclectic political mix of the mid twentieth century sparked the peace movement, gave rise to the new women's movement and the environmental movement; all of which affords priority to ecological thinking in support of the Ecofeminist perspective on the environment. [2] Much of the literature of ecofeminist philosophy focuses on environmental ethics, environmental justice, and the possibility of creating an "earthcare ethic...premised on a dynamic human relationship with nature." [3] In the art world, the challenge to the "hegemony of Modernism" overlapped with "feminism in the arts" to address the dialectical relationship between nature and culture.[4] Thanks, in part, to the world wide environmental movement, the environmental art movement spread out to include documentary and filmic practices, and video installation. As well included is television programming such as the popular National Geographic and PBS series on Nature, the CBC 
production of The Nature Of Things with host Dr. David Suzuki and the enormously successful BBC series, State Of The Planet with the influential and eminent Sir. David Attenborough.

The contemporary artists' interest in the environment has spurred on what has become recognized as an Ecoart movement. The Ecoart movement is local, regional and global. In addressing the relationship between cultural self-determination and sociocultural activities, Ecoart practices honour the harmonic beauty of the natural world. With an emphasis on social concerns, much of its witty, critical, political, ethical and aesthetically attuned works are directed toward reconnecting or restoring vital links between humanity and the natural world. The art works and the Ecoart productions, which I reference, may be viewed "on line" at numerous Internet art galleries, international art web-sites, and public art gallery web-sites.

The first part of this paper considers human activities that have changed the character of the living environment. I also draw insights from prehistoric and ancient civilizations that have used visual symbols which attest to the timelessness of art; not only as cultural ritual, but also art as a carrier of cultural and traditional knowledge. In creating an environmental narrative, philosophical theories of ecofeminism and ecological humanism provide a focus on principles of conservation and plant protection. From this, I address a profound shift-a sudden; if not a basic change - in sociocultural values turned toward ecological thinking that encourages good environmental practices. As I address ecosystem integrity, plant biodiversity, sustainable use of natural resources, I exemplify practical activities directed toward the protection of the natural environment. The second part looks at the ecological debate between the necessity to acknowledge the economic benefits of Nature's bountiful yield and the need to reduce the high price we level on Nature. The final section draws attention to artistic practices that use the language of the landscape as subject to ascribe value to Nature. By offering a dialogical critique on the use and abuse of the precious bounty of the land, waterways, oceans, and the biosphere, my presentation conveys the theme of hope directed toward a good outcome for Planet Earth.

\section{Conservation and Preservation}

Travel has enriched my understanding of certain artistic accomplishments belonging to prehistoric and ancient cultures. In gaining knowledge of historical societies I have also raised my awareness about ethical practices in preservation and conservation that point not only to economic considerations, but also to cultural choice. For instance, while nineteenth century archaeological field work in the Maya-Toltec area, in the Yucatan peninsula, Mexico, uncovered prehistoric ruins; it was anthropological inquiry that introduced theory and speculation about its culture and its ancient civilization. Political decisions of the twentieth century are what led to the practical preservation of the cultural sites. Specifically, in 1972 the Mexican authorities placed all of the archaeological pre-Columbian monuments and historical artistic sites under the guardianship of the Mexican Federal Government. With an inviting economic upswing, resort areas such as Cancún, were developed. And in the 1980s, tourism officials turned their attention to socioeconomic policies that made previously inaccessible zonasArqueológica, open to the touring public.

The Maya-Toltec site of ChichénItzá is claimed by UNESCO as a World Heritage site. It is one of the most renowned and most visited archaeological complexes in all of Mexico. As a tourist I have had the opportunity to visit this vast cultural museum. Central to the complex stands an enormous step-pyramid that is aligned with the setting sun of the spring and autumn equinoxes. Four colossal stone sculptures depicting a feather-headed serpent mark each side. At the equinoxes the shadow image of a snake appears to slither along the northwest side of the pyramid. Close to the pyramid stands what is believed to be a proto-observatory. A rounded "astrological observation" building stands at top. It has openings aligned with the cardinal directions, and with the traverse path of Venus. From the Mayan interpreters, I learned that the Maya have lived in the area since time immemorial. Evidence of ongoing occupation exists from prehistory, and some of their ancient cultural traditions survive to be found in the living Yucatec Maya of this day.

Key to my inquiry is the fact that from ancient times the Maya developed a prosperous agricultural society built on the cultivation of corn, beans, peppers, and squash. Evidence of their cultural knowledge of the land, of the animals, of the growing seasons, and of seasonal change may be seen in visual narratives that are carved into the limestone walls and square stone pillars that mark or enclose the ChichénItzá site.

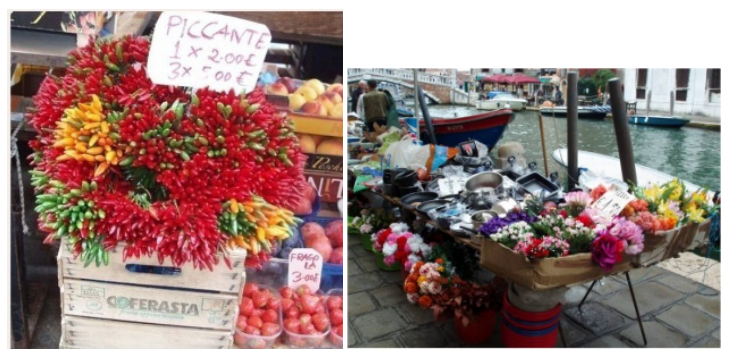

Figure 1.globaltrade in seeds and plants bring fruits, vegetables, and exotic flowers to markets

Evidence also exists of a vast trade network, most likely accessed through a complex system of roadways that are yet to be thoroughly examined. Thanks to accepted world-wide trade practices in commodities and in seed and plant exchange, products such as the tomato, potato, beans, corn, peppers, and flowers arrive from the Americas to appear in markets throughout the world. In return, European plants appear everywhere too. My point is, as seed and plant exchange has altered peoples' lives worldwide, it has also altered the natural landscape. 
For example, when wheat arrived in the Americas, to enrich the economic landscape, it changed ecological facts of the natural landscape; and eventually to almost edge out the native prairie grasses. The European Knapweed, genus Centaurea, has not contributed economic value. All varieties of Knapweed exude a toxic substance through its root system, thus deterring the natural growth of wild plant and native grass species. It spreads freely and eradication with chemical sprays and the use of biological weed control has come at a high cost both to agriculture and to the health of the living habitat.

The Sainfoins, Onobrychisviciifolia are Eurasian herbs belonging to the legume family. Introduced into Canada in the late 1900s as a forage crop the plants are deemed both beautiful and beneficial. Sainfoins naturalize easily and are drought resistant and frost hardy. The Sainfoins are good for domestic animals and for wild animals such as elk, deer, and moose. The pretty pink flower is attractive to the honey bee for its sweet nectar and in view of honey production the Sainfoins are much valued by the beekeeper.

Baby's breath, genus Gypsophila, is another imported Eurasian plant species that naturalizes easily. As a garden escapee, it scatters its seed far and wide. In the southern Interior of British Columbia the plant invades the dry grasslands, and into the pine forests. Still, this "gypsum loving" garden plant is much coveted by the florist. The common weedy Dandelion, Taraxacumofficinale, also imported from Europe, finds register among the noxious weeds of Canada. So thoroughly eradicated in certain parts of Europe and the UK, Dandelion seed now appears listed in specialty seed catalogues. As an early spring source of pollen and nectar, the Dandelion is a plant essential to the survival of the insect pollinators such as wild bees, and the honey bee population.

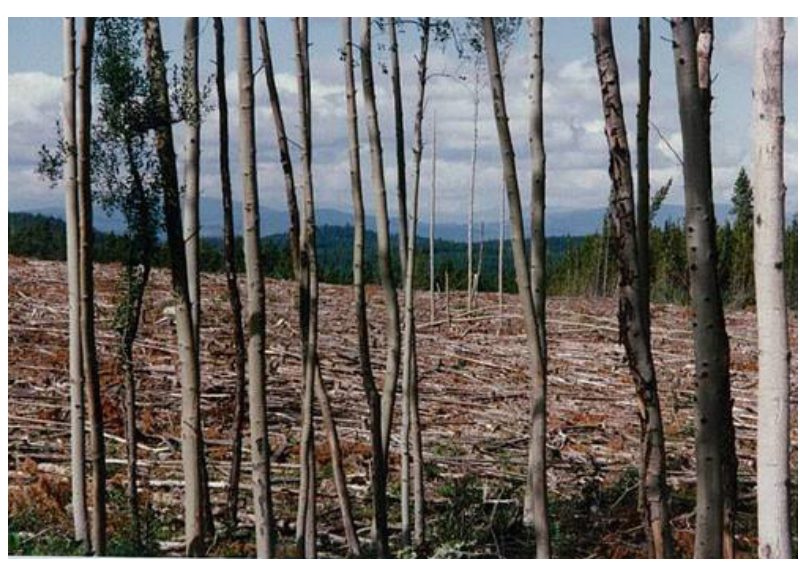

Figure 2.a 'cut-block' in south central British Columbia awaiting 'reforestation'

The European honey bee, Apismellifera, arrived in British Columbia over one hundred and fifty years ago. From the initial two colonies, apiculture spread quickly throughout the province along with European settlement. And along with that, came vast quantities of imported European plant species. While introduced plants may be deemed precious as food crops and animal fodder, many of the imported wild plant species of Europe, are listed among the common invasive weeds of Canada.[5]

The highly invasive European Broom naturalizes extensively, and where it finds good growing conditions - along the rail beds and road right-of-ways of Europe, and in Canada and the United States - it takes over. The Canadian artist Emily Carr, well known for her love of Nature has this to say about Broom:

Gilding, Jazzing, Blatantly gorgeous! Broom surges over the land commandeering every vacant lot. While tourists intoxicated by Broom's yellowness and smell rave, inhabitants turn from the red-hot-yellow-smell and the teasing pollen that makes them sneeze - shut their doors and windows to keep her out. Farmers curse her for devouring the land...Broom on the hill, Broom along the highways, fields of broom, mountains of broom...In the dry season Broom is a serious fire hazard...She is not one of our native wild flowers. An early settler brought his pockets full and scattered the seed.[6]

Such are the stories; migrants arriving in new and strange lands with "pockets full" of precious seeds. Seeds for cultural ritual, seeds carried on long journeys to be eaten as food, seeds brought from a beloved homeland and planted in the hope of creating a new and prosperous life in farming, seeds scattered to change a strange landscape into something familiar, and seeds planted from a desire to keep the memory and dream of home alive. By definition, however, many imported plants compete with native wild plant species, they are deemed neither useful to farmers nor good for the land. In addition, because imported plants have few predators, they often take over the landscape, "....as weeds we see them everyday...weeds inhabit lawns, gardens, and waste places. In the country they line every roadside and grow vigorously in all fields....Weed control is a never-ending battle."[5]

In Scotland I visited the Black Hills Estate, near Elgin, to view the gardens where there are more than 300 imported Rhododendron plants. Collected in the Himalayas in the 1920s the plants have naturalized to edge out native European wild plant species. Travelling on, through the Scottish Highlands, I stopped to photograph a number of tree farms. Viewed from the perspective of the UN Convention on Biological Diversity, the astonishing numbers of monoculture plantations of Ponderosa pine - an imported tree species native to British Columbia - go against the objectives of the Convention. From an environmental justice point of view, the application of toxic sprays, chemical fertilizers, pesticide sprays, and chemical herbicides typically used in monoculture tree farming is far and away from an ethical approach to "earthcare." [3] Chemical application not only destroys plant biodiversity, but repeated applications eventually leaves the habitat unsuitable for plant growth. I was told by an informant that after several timber harvests, the economic yield of a monoculture tree farm typically falls off. A remedy to improve this is to clear-cut the remaining trees, and to leave the infertile ground fallow 
to rejuvenate naturally. At the tree farm which I visited, the long term plan directed toward restoration of the land and ecological balance includes the reintroduction of wild plants and trees species native to Scotland. In the interim, I noted, grasses, ferns, mosses, and a prolific bluebell had already filled the empty spaces. I later learned that the abundant blue flower was not the lovely "Bluebell of Scotland" but a highly invasive variety, imported from the Continent.

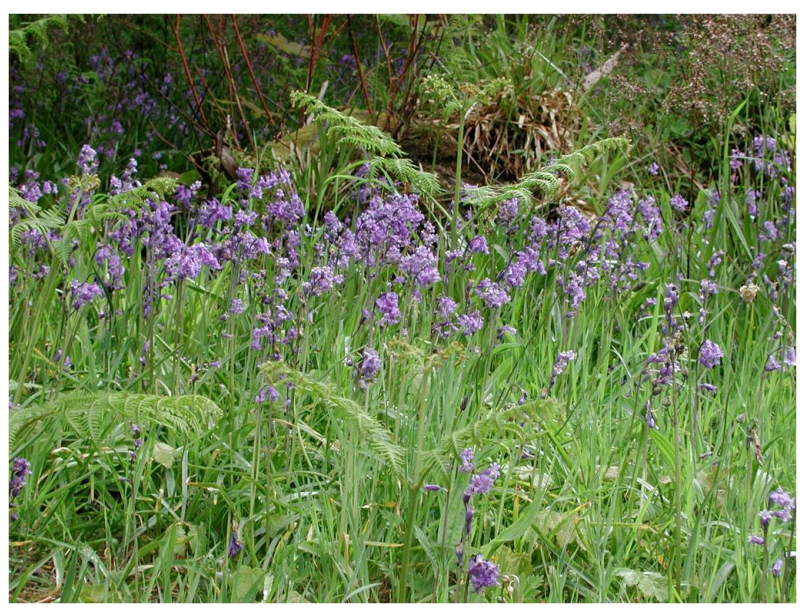

Figure 3.thereintroduction of native plants is meant to improve the soil at a tree farm in Scotland, but an invasive species flourishes here too

Vandana Shiva, a well know environmental activist, has recognized the privatization of land for monoculture farming practices and monoculture forestry management as the exploitation and the destruction of biodiversity in the name of "westernizing economic categories." [7] Shiva elaborates on the damming of rivers, privatization of land for revenue generation, and the practice of monoculture:

...it goes far beyond a neutral concept of productivity...The expansion of cash crops undermined food production...the development process has deepened, instead or reversing, the process of underdevelopment....Development projects have destroyed women's productivity by removing land, water, and forests from their management and control, as well as by the ecological destruction of soil, water, and vegetation systems so that nature's productivity and renewability have been impaired.[7]

Shiva identifies economic crop production as a bias against nature and against indigenous peoples. This bias, she claims, is not only a "violent" form of control that "denies the activity of nature and life" but it also has "generated a crisis of survival" for traditional communities. These facts are now well known; in the association between economic systems where the natural forests have to be "developed into monoculture plantations," and where the "river systems have to be controlled," biodiversity is lost, and so too the land. Thus, as Shiva points out, such systems displace indigenous people from traditional land uses. Following Shiva's analysis, it must be noted that expanding privatization of land for monoculture cash crop is deemed responsible for the destabilizing effects of both land and plant biodiversity: not to forget to mention ethical issues that arise in association with use and over use of chemical fertilization, herbicides and pesticides.

In India, I travelled to the "roof of the world" to view the Annapurna Massif in the Himalaya Range. Driving from Almora the picturesque hill country is laced from top to bottom and side to side with small terraced farmlands. The important characteristic of the small agricultural footprint corresponds with the tranquil idyllic beauty of the rural countryside. This to suggest traditional farming communities, and organic agriculture; but that is a romantic view, according to Shiva. Her research indicates that many traditional farming communities have been destroyed by large scale economic farms and industrial development. Following Carolyn Merchant, restoring the natural environment, depleted by industry, ought to be a common goal. Realization could come through "levels of cooperation" directed toward community balance and ecosystem integrity, supported by a "...global partnership to conserve, protect, restore the health of Earth's Ecosystem."[3]

In the area of ecological thinking, the call for the restoration of the balance between nature and culture, hearkens back to Rachel Carson's 1962 analysis:

The earth's vegetation is part of a web of life in which there are intimate and essential relations between plants and the earth, between plants and other plants, between plants and animals. Sometimes we have no choice but to disturb these relationships, but we should do so thoughtfully, with full awareness that what we do may have consequences remote in time and place. [8]

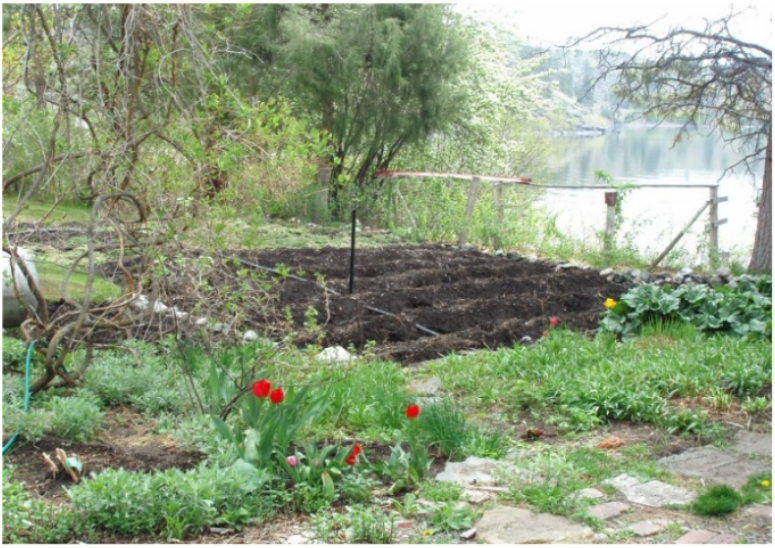

Figure 4. even a carefully tended garden plot will alter ecological systems

While the "100 mile diet" supported by the small kitchen garden offers sustainable ways to carry on an ethical relationship with Nature, native wild plant species are edged out. Even a carefully tended garden plot will alter the ecological systems needed to maintain the ageless link between the cycles of nature's renewability.

The Canadian photographic artist Edward Burtynsky offers a "visual essay" on the "man-made" agricultural landscape; which includes startling images of terraced rice 
paddies in China that cover the plain from corner to corner and in his written text, comments on aspects of such landscapes:

....My photographs reflect the impact of humanity, not its absence. They are pictures of our footprint, and the diminishment of nature that results. They are distressed landscapes: images of land, and now of water, that we have altered, or diverted, or transformed, or used in this unprecedented period of population growth, agriculture expansion, and industrialization. 1

Through the use of special cameras and shooting from the advantage of a fixed-wing aircraft, Burtynsky presents astonishing aerial views of a "diminished landscape" where nature, transformed by the large footprint of humanity, suffers. 2 Burtynsky's photographic images of pivot irrigation farming in High Plains Texas, for instance, reveal monoculture on a grand scale; this is a landscape pock-marked by industrial agriculture.

In practice, each irrigation pivot is connected to a well-head that draws water, night and day, from the Ogallala Aquifer. According to Burtynsky's research, water levels have dropped by more than ten percent since the 1950s, and should the current rate of water use continue it will take more than 6,000 years to refill this precious natural resource. 3 The greater part of the cash crop is alfalfa. It is cut, bagged, and shipped off to Japan to be used as fodder in the cattle industry. In the market, where meat is expensive, beef is a specialty food available only to a select few.

I wish now to focus on positive aspects of conservation and the protection of wild plant species that are directed toward the future. The Svalbard Global Seed Vault, located in the remote Norwegian Arctic, provides a means not only to protect "agricultural biodiversity" but also to preserve a wide variety of seeds. 4 The Canadian Edelweiss Growers provide a valued service in the conservation and protection of the "famously rare" European Edelweiss: and, they promise to ship seeds anywhere in the world. 5 From the tradition of seed and plant collection instigated by scientific research, the University of Cambridge is in charge of plant specimens gathered by Charles Darwin and the rare herbarium sheets, prepared by John Henslow. Recently I took the opportunity to visit the Linnean Society in London, which holds the distinction of caring for more than fourteen thousand plant specimens. At the Royal Botanic Gardens at Kew, I visited the Shirley Sherwood Gallery of Botanical Art. The Kew archives list more than two hundred thousand works of botanical art. Taken together these concentrated efforts not only retrieve the past, but they also encourage

1 On line at, "A decade of visual storytelling"

www.thewalrus.ca/photo-essays (first accessed October 2013).

2 For images and essays go to www.edwardburtynsky.com (first accessed February 14, 2013).

3 Ibid.

4 Go to http://en.wikipedia.org/wiki/Svalbard_Global_Seed_vault to view

the mission statement (first accessed March 15, 2014).

5 For images and more information go to www.edelweissgrowers.com (first accessed January 22 2014) practical ecological activities directed toward the future; for the conservation and protection of the precious vegetation of Planet Earth.

The American conservation group Ducks Unlimited began its land conservation and plant protection campaign in 1937. Their mission, to preserve the wetlands for waterfowl and wildlife habitat has spread to include international projects. This volunteer-based organization has ongoing conservation projects throughout North American, including Mexico, and in Venezuela, and Australia. According to the impressive fact sheet, of January 1, 2014, the organization has been "influential [in the] conservation of 118, 423,660 acres" in North America alone. Widely recognized for its youth education programs, the mission statement of Ducks Unlimited Canada is to protect and sustain the health of "precious resources" such as wetlands, and watersheds. 6

Other long term land conservation projects include the efforts of the Nature Conservancy. This group works regionally, nationally, and globally to protect endangered wetlands, prairies, and mountain habitats. Since 1962 Nature Conservancy Canada has helped to "...save over a million hectares of ecologically significant land across Canada."7 In British Columbia, the Nature Conservancy Canada works in four regions: The Canadian Rockies, Central Interior, the West Coast, and the Southern Interior of the Okanagan and Similkameen valleys and the Thompson Nicola Valley region. Collaborating with private landowners, ranchers, and governments to protect the grasslands and open forests, Nature Conservancy Canada recently acquired a ranch property in close proximity to the Nicola Valley. This delicate bioregion, which will be held in conservation for the future supports vast numbers of wildlife, including the endangered Burrowing Owl.

\section{Environmental Polemics}

There is a certain globalization of the concepts 'conservation' and 'preservation' that suggests cultural choice. Yet conservation and preservation of the precious "green mantel that gives life to the planet" has a contested, troubling, and conflict-ridden, history. Opponents of environmental protection claim that land conservation limits the potential of community growth. In the "jobs versus environment protection" argument, conservation comes at the expense of employment and tax revenue. 8 Communities near and around the oil rich mining areas of the Canadian province of Alberta attest to economic growth and to the demand for housing. The rapid growth of the City of Calgary,

6 For Canadian program information go to www.ducks.ca/education and for information on international programs go to

www.ducks.org.media/global/_documents/StateFactSheets (both first accessed March 24, 2014).

7 For Canadian conservation information go to www.natureconservancy.ca (first accessed March 24, 2014).

8 For a longer discussion see "Environmental Protection Change, and Economic Development in the Rural Western United States" by Paul Lorah, University of St. Thomas, and Rob Southwick of Southwick Associates, Inc., at http://www.voiceforthewild.org (first accessed March 6, 2014). 
for instance, shows unprecedented real estate development that has huge economic gain, but it comes with a high ecological cost. In just a few years, real estate development has spread to engulf hectares of fertile farmland. Ironically, community development is needed: homes for families, schools, hospitals, roads, services; while at the same time, such development destroys fertile farmland, and endangers the life cycles of prairie animals, fragile grasslands, and precious native plant species.

Shifting the focus to developments in industry-open pit mining, energy extraction, and timber harvesting - the economic argument claims that natural resource extraction is necessary for overall economic stability. The countering argument, against environmental devastation and ecological damage perpetrated by industry, supports economic developments in parks and recreation, and the creation of Ecotourism.

In British Columbia, environmental protest has proven an effective way of protecting vast ecological areas from unchecked development. In the 1990s, hectares upon hectare of old growth rain forests were slated for harvest. Often the site of confrontation between environmental activists and loggers, direct environmental action claim victory in Clayoquot Sound, on Vancouver Island and in other places too. 9 The environmental movement has also been instrumental in the protection of the Great Bear Rainforest. Located in the temperate zone of British Columbia, it covers an area of more than $400 \mathrm{~km}$ of lush 'old growth' coastal forest. 10 Another example is the protection of GwaiiHaanas, an island located at the southern tip of HaidaGwaii-the Queen Charlotte archipelago. While the logging companies argued for clear-cut logging and loggers their rights to jobs, the Haida First Nation argued indigenous rights to the land. 11 In addition, Haida elders provided traditional knowledge about the sacred cultural environment; and they presented unquestionable facts proving the continuous Haida occupation of the land. If not for the combined efforts of a determined group of environmentalists and First Nations peoples, hectares upon hectare of old growth coastal rain forests would have been lost to the devastating practice of clear-cut logging.

In the interior mountain ranges and the 'dry-belt' pine forests of British Columbia, the naturally tight growth pattern of the Lodgepole pine proves vulnerable to the enormous appetite of Dendroctonusponderosae, the Mountain Pine Beetle. Native to northern British Columbia, the astonishing population explosion of the Mountain Pine Beetle is thought as the result of warmer winters due to

9 For more information and images go to

www.cathedralgrove.eu/text/03-Europeans-care-4.htm (first accessed December 2013).

10 For more information, go to www.savethegreatbear.org and click on More Images (first accessed October 2013).

11 In Canada, the term Aboriginal is the legal designation for indigenous Native Indian and Inuit people. From the mid 1980s the term First Nations came into wide use. Although not a legal term it has been adopted by Canada's 614 "Indian Bands" and is now used politically to identify individual people and First Nations groups such as The Assembly of First Nations, and the National Center for First Nations Governance. climate change. Following Dr. David Suzuki, “...in British Columbia alone it took less than 10 years for swarms of the Mountain Pine Beetle to eat their way through 18 million hectares old growth Lodgepole pine forests." 12 The beetle has now made its way to Alberta and into the boreal forest. In British Columbia alone, dead or dying first growth pine forests have been clear-cut; this in part to stave off the invasion, and in part as a precaution against forest fires. As a result of these massive logging operations, the timber market has been flooded, lumber prices have dropped, jobs have been lost and despite replanting projects, entire logging communities have suffered in the economic downturn.

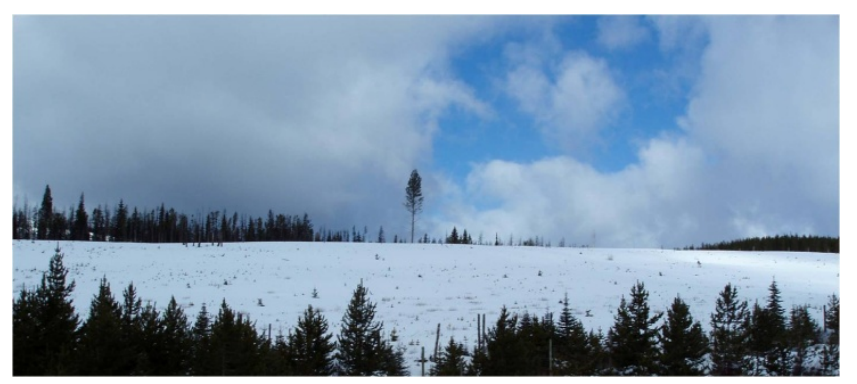

Figure 5. with 'new ideas' in silviculture old growth 'mother' trees are left standing to encourage plant biodiversity, here in a clear-cut pine forest devastated by the Mountain Pine Beetle in south central British Columbia

With new ideas in silviculture "big trees" are left standing in clear-cut sections. Dr. Suzanne Simard, forest ecologist at the University of British Columbia, provides research to show that a complex underground web of life connects big trees and plants, which clear-cut logging destroys. Her research reveals that, “...brilliant white and yellow fungal threads in the forest floor...transport carbon, water and nutrients upon which the health of the forest relies." 13 When a big tree is cut down, plant biodiversity and the survival rate of the younger members of the forest, is substantially diminished. Simard elaborates:

The big trees were subsidizing the young ones through the fungal networks. Without this helping hand most of the seedlings wouldn't make it....At the hub of a forest's mycorrhizal network stand the 'Mother Trees'. These are large, older trees that rise above the forest, a concept illustrated in the movie Avatar. These 'Mother Trees' are connected to all the other trees in the forest by this network of fungal threads, and may manage the resources of the whole plant community. 14

Following Simard, as nature is like an interconnected community, environmental activists have been quick to adopt the theme of Native Knowledge, which holds that all life is interconnected. Drawing upon ancient cultural wisdom,

12 See www.cbc.ca/natureofthings/m/episodes/beetles and click on images (first accessed April 2014).

13 For more information and images go to

www.sifi.se/wp-content/uploads/2012/06/Suzanne-W.-Simard

14 The movie Avatar is a 2009 epic science fiction film directed by James Cameron. For images go to www.wikipedia.org/wiki/Avatar (2009 film) (first accessed March 24, 2014). 
followers of traditional Native Knowledge deem that the life-giving properties of the natural world ought to be protected not only for the sake of the environment, but also to insure the health and balance of future communities. Dr. David Suzuki explains:

Seen in this light, Native knowledge and spiritual values are not simply 'natural resources'...for non-natives to mine, manipulate, or plunder. They are, and will always be, the precious life-sustaining property of First Peoples: sacred symbols encoding the hidden design of their respective universes; mirrors to their individual and collective identities; and ancient and irreplaceable maps suggesting possible paths to inner as well as ecological equilibrium with the wonder, ever-changing world.15 [1]

First Nations' environmental activists also point to industrial activities that are not only endangering the spiritual and precious web of life that envelops the Earth, but also to "big industry" practices that are disturbing the traditional life ways of indigenous communities throughout the world. Environmental justice and indigenous land rights have been addressed by the United Nations in the draft document of the Universal Declaration on the Rights of Indigenous Peoples. [1] In Canada, Amnesty International addressed First Nations land issues — as indigenous land rights belong to the realm of human rights under the Canadian Constitution. 16 Most recently, issues of indigenous human rights and environmental ethics were addressed by Archbishop Desmond Tutu, at a conference in Canada holden at Fort McMurray, Alberta, in May 2014.17

\section{Visual Culture}

In the art world, in connection with Plato's idea of "organic unity" Aristotle's doctrines are basic to critical inquiry into the relationship between nature and human cultural traditions. [9]. For Aristotle, experience tells us that things are interconnected, rush centuries ahead and we hear from David Hume that sentiment, interconnected with ethical judgement and aesthetic enjoyment, advances knowledge. In the sense, that philosophy provides groundwork for the environmental arts to claim an interconnected affinity with nature, a strong message comes to temper how we live, how we interact, and to remind us that our actions have an impact on the interconnected life of the planet Earth.

I have little doubt that urgent, pressing, problems of our society will change any time soon- even by well intentioned art interventions. Nevertheless, in this section I review

15For more information go to www.davidsuzuki.org (first accessed April 10 2014).

16 For information about human rights issues in Canada go to www.amnesty.ca and click on spring 2014 (first accessed May 2014), or see Amnesty Vol. 13, No.1.

17 Also see www.thestar.com/news/canada/2014/05/06 and click on related issues (first accessed, May 2014). To view a report by Bob Webber, on aboriginal treaties and climate change, go to www.thestar.com/news/canada/2014/05/06 (first accessed, May 2014). artistic practices that use the language of the landscape to ascribe value to nature. I highlight creative expression aimed toward raising awareness of the alarming situations described earlier, and I discuss innovative artistic works that appeal to deeply held sociocultural values, ethics and beliefs. As contemporary environmental artists call for new ways of relating to nature, in works directed toward changing fixed notions about divisions between nature and culture, I offer a route back to the hope for a good outcome for Planet Earth.

From the romantic poets such as Wordsworth and Shelly, and landscape artists like Rosa Bonheur, Van Gogh, and Cézanne - all of whom drew inspiration from daily walks in nature - the environmental artist is often associated with the impulse to communicate with nature. In the 1930s, the Canadian artist Emily Carr produced a prodigious body of work, based in part on the theme of communication with nature and in part on the theme of the living forest. Starting from her deep belief that all things are interconnected, Carr wrote about her knowledge of the forest and her belief that nature and life are interconnected, "...you can sit on the [forest] path and look down on the snarl of green. It is lovely. Suddenly, its life envelopes you, living, moving, surging with being, palpitating with overpowering terrific life, life, life." [10] In her nature writing Carr describes a personal contact with the earth through a 'felt' sensation of being in nature, "...the liveness in me just loves to feel the liveness in growing things, in grass and rain and leaves and flowers and sun and feathers and fur and earth and sand and moss. The touch of those [is] wonderful." [10] Claiming the visual language of the landscape in her paintings, Carr projects her idea of nature and the living forest as, "...world life-energy." [11]

In March 2014 the curators at the Vancouver Art Gallery, Vancouver, British Columbia, brought a collection of Emily Carr's landscape paintings together with Edward Burtynsky's photographic narrative to create a "dialogue" about subjective approaches to nature. 18 Among the most cherished of Carr's paintings are "sweeping forest canvasses" belonging to the Deep Forest series. In a work titled Above The Gravel Pit, Carr reveals an interest in the character of the "denatured" landscape where, in her words, "...nature has not had time to heal the scars and holes yet." [10] As this painting depicts results of clear-cut logging practices that destroy the forest and the life of the forest floor, Carr's keen sense of observation also points to truths of economic systems that consider the forests primarily as plentiful sources of timber.[12] In Scorned as Timber, Beloved Of The Sky, Carr depicts one lone tree left standing tall against the devastated logged-over terrain. 19 Here, Carr's interpretation of the spirit of the forest is expressed as "symbolic of spiritual energies." [11] In relation to the interconnections of life's energy, this is a landscape depicted as horrific in scope and breath-taking in its splendour. As

18 Go to www.vanartgallery.bc.ca and follow the links to find Emily Carr (first accessed January 2014).

19 For more images go to www.vanartgallery.bc.ca and follow the links to Carr (first accessed April 2014). 
such, Carr's transformations of the landscape are well within, "...the formulation of an aesthetic of the sublime." Following Hans-Georg Gadamer, the "aesthetic consciousness" is all about the question of truth. In relation to art, this truth is always linked to, "... a crucial point of access to fundamental truths about the world...." [13]

With a focus on the use and misuse of natural resources and the impact this has on nature and on the landscape, Burtynsky's photographic narrative brings the viewing public face to face with certain truths about unsustainable global developments. 20 Burtynsky's reference to the impact of economic development on communities, on the land, and on natural resources raises questions associated with concepts of conservation and the protection of precious plants that support life on Planet Earth.

In his documentary film, Water, Burtynsky's images draw attention to the horrific force of water that is needed to clear silt from behind the Xiaolangdi Dam on the Yellow River, China. As his filmic transformations unfold, there are unsettling, awesome, and disturbingly beautiful images that hearken to the aesthetic of the sublime. In contrast, a still photograph of the Three Gorges Dam appears picturesque in the morning mist.21 In his essay, Burtynsky writes that by damming the majestic river 1.13 thirteen million people have been relocated, jobs lost, precious farmland flooded: and, invaluable cultural/historical sites, destroyed.22

In the fall of 2013 I was able to travel to the Greek Island of Crete. While there I had an opportunity to visit the ancient Minoan cultural site at Knossos - albeit a reconstruction by Arthur Evans. The autumn light of September lit up the walls, some of which carry decorative images. Later the same day, I visited the world famous Archaeological Museum in Iráklio (Heraklion), which holds a vast collection of Minoan art. Evidence of the Minoan interest in nature and proof that the Minoan culture valued the precious plants of Crete, is brought to the present in exacting botanical detail of flowering plants that are depicted on a multitude of jars, containers and in fresco fragments that belong originally on the walls of buildings at Knossos. 23

The island of Crete is indeed rich in plant life. According to one travel book, there are over two thousand plant species, more than 180 native wild plants, a wealth of precious native bulbs, and the Mediterranean cypress, a tree species native to Crete that is listed as endangered. In their book Orchids of Crete and their Conservation Dr. Rosemary John and Julie Jones write of the very rare and endangered orchids of Crete. 24 Noting the loss of precious plants to the illegal trade in the export of rare endangered plants and bulbs, they also note the loss of plant habitat; this, due to the influx of mass tourism, the demand for holiday houses, and the rapid

20 For images go to www.vanartgallery.bc.ca and follow to links to Burtynsky (first accessed March 2014).

21 For images, go to www.edwardburtynsky.com (first accessed February 14, 2014).

22 Go to www.thewalrus.ca/photo-essays (first accessed October, 2013).

23For images go to www.heraklion-crete.org/ (first accessed May 2014).

24 www.orchidconservationcoalition.org/pr/flowersofcrete and click on images (first accessed January 2014). growth in housing development.

Within the environmental art movement, there are many approaches that connect the visual arts to political ideology and to broad social issues such as, social justice, the peace movement, and the planetary environmental crises. Working from the concept of a "personified" Earth, some ecofeminist artists draw inspiration from the Gaia hypothesis; this not only to claim that nature and spirituality are one, but also to express an embodied attachment to the enduring beauty of the living Earth. From the "pluralism of the 1970s" that gave rise to the Conceptual and Process Art movements, many artists chose to "dematerialise" the art objects by moving out of the studio altogether, and to work directly in the landscape. [4].

The British artist Richard Long, for instance, turned away from making art objects to concentrate on creating a sensuous connection with "integral parts of the landscape" by walking alone in the landscape. Claiming this activity as process art Long has stated, “...A walk expresses space and freedom and the knowledge of it can live in the imagination of anyone." [14] Placing the emphasis on the physical experience of walking alone in Nature, Long's process works are relevant to contemporary environmental art practices. The Canadian artist Janet Cardiff's seminal "audio walk" in nature - created in 1998 at Wanäs Sweden - belongs to this tradition. In what is known as a collaborative authorship, Cardiff teamed up with fellow Canadian artist George Bures Miller, and to date they have produced more than a dozen imaginative video audio walks. 25

Points I wish to connect tie these and other so-called 'postmodern' artistic practices within the international language of the landscape. Most notably, to the artistic conversation that is going on in the Ecoart movement with regard to concerns about land conservation, species preservation and the future of the planet. This global contemporary movement is cross-cultural, dialogic, interactive, technical, eclectic, optimistic, political, and witty. Many Ecoart images are accessible to the wider public as they may be viewed "on line" simply by going to a public art-site, or by entering a particular artist's name.

Swedish artist Erik Johanssen, for instance, relies upon the web as a form of 'gallery space' to exhibit his works. Billing himself as a contemporary "retouch" artist, Johanssen uses digital imaging that allows him to "toy" with the language of the landscape.26 Creating stark contrasts between cultural and traditional photographic views of the natural countryside Johanssen admits to using René Magritte inspired juxtapositions, which in a witty turn may be read in relation to use and abuse of the land and waterways.

The Canadian artist Rebecca Belmore's visual object/performance piece, Speaking to their mothers, has been used politically to get people to step up and speak for

25 This collaborative work may be viewed at the Vancouver Art Gallery, June-September 2014. For more information and images, go to www.vanartgallery.bc.ca (first accessed May 2014).

26www.erikjohanssonphoto.com/ 
nature and for environmental justice. 27 In the name of protecting the precious plants of the earth, this installation has been used in an effort to wake people up to the dangers of unchecked energy extraction - for economic gain - as this too has been argued by Suzuki as belonging to "an ecologically destructive worldview."[1] To "big industry" the living earth is simply "overburden" lying in the pathway of energy extraction. Although mining and oil companies working in Canada must promise to reclaim extraction sites, facts of the extraction process are such that any effort to rejuvenate the damaged earth is an almost impossible task. Evidence of long term environment devastation and industrial pollution can easily be found in the massive Athabasca oil sands project in northern Canada, at exhausted mine sites and quarries, and at mine tailings ponds, far and wide. 28

Form and content are part of the theme of collective authorship in which artist herman de vries and his wife Susanne have created a visual statement based on the concepts of land conservation and preservation. In a work titled di wiese/the meadow they obtained a section of land, which they have left to lie fallow. They then claim the living environment and the rejuvenation process as art under the category of nature's art. 29

In April, 2014 Rhonda Neufeld and Rodney Konopaki collaborated together on a site-specific installation for the Kamloops Art Gallery at Kamloops, British Columbia. Titled Suggestions from Kamloops the artistic work begins with a walk in nature. Holding a drawing paper between them as they walk, they record their subjective 'felt' experiences in nature. Back in the gallery, coloured pigments are rubbed into the paper to bring out the scratches, lines, and marks. These drawings are not compositions in the sense of the landscape as picturesque scenery. What they represent are embodied subjective experiences, presented as a visual text, wholly dependent upon a wide range of physical stimuli in relation to bodily experiences in nature. In addition, topographical lines were drawn on the gallery walls to depict points of reference that correspond with drawings fixed to the walls. Although Neufeld and Konopaki claim an autonomous art, the political language is there non-the-less. This is due, in part, to the placement of drawings that are meant to reveal specific surface regions in the physical landscape; and in part, due to facts of installation art.

Installation art is a well-known artistic strategy directed toward an investigation into the truthful nature of reality. Taken together with juxtaposition, which combines disparate elements to bring new meaning to immediate objects of perception, the viewer is encouraged to reason out the connection between the eclectic images and to bring new meaning to the viewing experience. In this sense, given that the contemporary viewing public is well aware of the flow of

27 For images, go to www.canadianart.ca (first accessed January 2012). 28 For alarming images of tailings pond breaches, go to 'Google' and enter tailings pond + images

29 See www.hermandevries.org for images (first accessed June 15 2010). language and the politics of installation art, the political is brought to the viewing experience.

In my own installation work, titled $A$ Landscape of Unsettled Emotion and Changing Ecological Conditions, I use ice and melt-water to achieve a visual transmutation of form. $30 \mathrm{In}$ the viewing experience, the visual change of form, from a static state of ice to a dynamic state of the life-giving element of water, is highly symbolic of the great environmental changes brought to systems of nature by climate change.

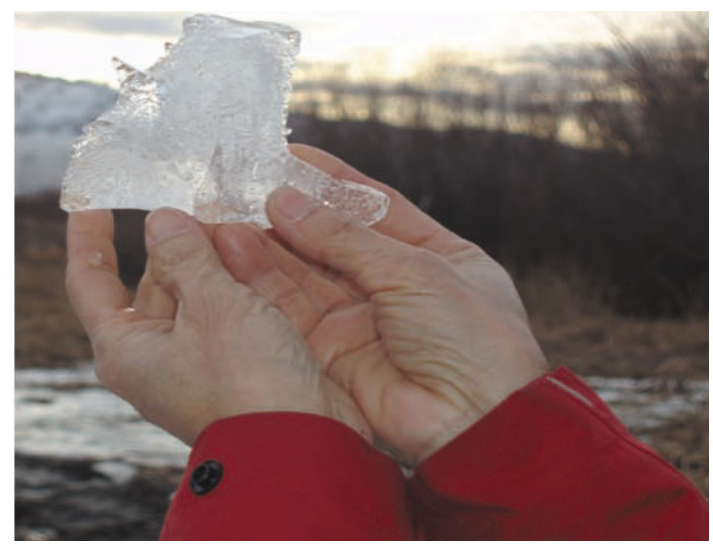

Figure 6. a visual transmutation of form

As such facets of experiential viewing releases emotional currents, an embodied state of disruption is suggested. As this belongs to the human psyche, the eclectic images translate 'felt' emotional shifts that belong to the realm of sensual reality. As the viewer reasons out the interconnected meaning, the greater implication of this work is meant to raise public awareness about the impact of climate change and the attendant loss of critical aspects of the natural world; this due also, and in part, to unchecked resource harvesting.

In a recent documentary film Tipping Point, with reporter Bernice Notenboom, scientists identify twelve dangerous tipping points associated with climate change that have the potential to alter weather patterns around the world.31 Such change will, no doubt, alter planetary growing patterns that will in turn endanger the Earth's precious, “...green mantel of plants that give life to planet earth."[8].

I close with reference to an enormous art installation titled The Weather created in 2003 by artist Olafur Eliasson for the Turbine Hall of the Tate Modern in London. What sets Eliasson's installation apart from entertainment is his treatment of the "dramatic illusion" effect. [9]. To paraphrase Marcella Beccaria, a curator of the installation, visitors appeared to ignore the obvious technical components needed to make up the installation - the back-lit lighting, the evaporating mist, the mirrors installed along the entire length of the ceiling - and chose instead to meet, celebrate and embrace the staged illusion of the sun. 32 This was later

30 To view this work, go to SaatchiGallery.com and follow the links (first accessed May 2014)

31 To view filmic segments go to www.knowledgenetwork.ca/programs (first accessed February 20, 2014).

32 For images, go to www.tate.co.uk (first accessed February 10, 2014). 
confirmed in conversation with a frequent visitor to the installation who opined, that the viewing public appeared to be responding to the artistic imitation of the sun as if they were experiencing an emotional primitive relationship with the ancient symbol of life.

\section{Summary and Conclusions}

Globalization of the concepts 'conservation' and 'preservation' suggest cultural values and choice; yet in practice, land and water conservation and the protection of earth's precious plants has a complex and troubling history. Thanks, however, to the efforts of dedicated environmentalists and groups working together with societies like the Planta Europa Foundation, national and international success stories may be told.

In the case of environmental and ecofeminist philosophy, new narratives in support of conservation and the protection of plant species are directed toward creating a partnership ethic as a guide for ecological thinking. While environmental activists and First Nations community leaders speak from a belief that all life is interconnected, research from Forest science and Earth system science can explain the interconnectedness of all aspects of Earth. Taken together with visual storytelling from the dust of time through the dawn of history and into the present day, the artistic conversation is not only integral to the age-old search for identification, but also integral to the relationship between the spiritual world and the material world. By placing the arts within the ecological vision of the interconnectedness of the Earth's system, the environmental art movement stresses the possibility of reconnecting humanity with the beauty of the natural world. As such, the ethico-aesthetic reality helps to encourage the wider public to get involved in practical activities that have a future: not only for the sake of humanity, but also to provide a route back to the hope of a good and peaceful outcome for Planet Earth.

\section{REFERENCES}

[1] David Suzuki. A Personal Forward: The Value of Native Ecologies. In: Wisdom of the Elders, Knudtson Peter, Suzuki David. Toronto: Stoddart Publishing; 1992, p. xxiii: 204-208: xxv.

[2] Plumwood Val. Environmental Culture The ecological crisis of reason. New York: Routledge; 2006.

[3] Merchant Carolyn. EARTHCARE WOMEN AND THE ENVIRONMENT. New York: Rutledge; 1995, p.6: 170: 216-219.

[4] Chadwick Whitney. Women, Art, and Society. London: Thames and Hudson, 1990.

[5] Mulligan Gerald A. Common Weeds of Canada. Toronto: McClelland and Stewart; 1976.

[6] Bridge Kathryn, editor. Emily Carr Wild Flowers. Victoria: Royal British Columbia Museum; 2006, p.34.

[7] Shiva Vandana. Development as a New Project of Western Patriarchy. In: Diamond, Irene and Gloria Feman Orenstein, editors. Reweaving The World The Emergence of Ecofeminism. San Francisco: Sierra Club Books; 1990, pp. 189-200.

[8] Carson Rachel. Silent Spring. New York: Fawcett; 1967. P. 64.

[9] Hutton, James, trans. Aristotle's Poetics. New York: W.W. Norton; 1982.

[10] Carr Emily. Hundreds and Thousands The Journals of Emily Carr. Toronto: Clark Irwin; 1966, p.199: 241-242.

[11] Shadbolt Doris. Emily Carr. Vancouver: Vancouver Art Gallery; 1971.

[12] Tippett Maria. Emily Carr A Biography. Toronto: Oxford University Press; 1979.

[13] Lawn Chris. Gadamer: A Guide For The Perplexed. London: Continuum; 2006, p.87.

[14] Lippard Lucy R. OVERLAY CONTEMPORARY ART AND THE ART OF PREHISTORY. New York: Pantheon Books; 1983, p.129 